\title{
HUBUNGAN DURASI KERJA DAN POSTUR TUBUH DENGAN KELUHAN LOW BACK PAIN (LBP) PENJAHIT NAGARI SIMPANG KAPUAK KABUPATEN LIMA PULUH KOTA
}

\author{
Shalsa Devira'); Burhan Muslim ${ }^{2)}$; Basuki Ario Seno ${ }^{3)}$; Darwel ${ }^{4)}$; Erdi Nur ${ }^{5)}$ \\ Poltekkes Kemenkes Padang
}

\begin{abstract}
Low Back Pain $(L B P)$ is pain in the waist or lower spine that can be felt up to the buttocks and thighs. Many workers experience illness. Results The study was conducted on 9,482 workers in 12 regencies and cities in Indonesia, the disease experienced by workers was Musculoskeletal Disorder as much as $16 \%$ including Low Back Pain. This study aims to determine the relationship between work duration and work posture with complaints of Low Back Pain at Nagari Simpang Kapuak tailors, Lima Puluh Kota Regency. This research is quantitative with a cross sectional approach. Collecting data through a census of 43 tailors with interviews and questionnaires. Data analysis with univariate, bivariate and Chi-Square statistical test. The results of the study found that $58.1 \%$ of tailors experienced severe complaints of low back pain. $72.1 \%$ are classified as risky age, $74.1 \%$ are female, $58.1 \%$ have a BMI at risk, $67.4 \%$ work with risky work duration, $69.8 \%$ work with risky work postures. There is a relationship between age $(p=0.017), B M I(p=0.013)$, work duration ( $p$ $=0.002)$, and body posture $(p=0.006)$ with complaints of Low Back Pain. To reduce the risk of Low Back Pain, tailors should relax and rest by stretching muscles, exercising based on the age of the worker, consuming foods that contain calcium, working with a balanced working time and doing an ergonomic work system
\end{abstract}

Keywords: Low Back Pain (LBP); working duration;Tailors

\begin{abstract}
Abstrak
Low Back Pain (LBP) adalah rasa nyeri pada pinggang atau tulang punggung bagian bawah yang bisa terasa hingga ke bokong dan paha. Penyakit banyak dialami oleh pekerja. Hasil Studi dilakukan terhadap 9.482 pekerja di 12 Kabupaten Kota di Indonesia, penyakit yang dialami pekerja adalah Musculoskeletal Disorder sebanyak 16\% termasuk Low Back Pain. Penelitian bertujuan mengetahui hubungan durasi kerja dan postur kerja dengan keluhan Low Back Pain penjahit Nagari Simpang Kapuak Kabupaten Lima Puluh Kota. Penelitian ini bersifat kuantitatif dengan pendekatan cross sectional. Pengumpulan data melalui sensus 43 penjahit dengan wawancara dan kuisioner. Analisis data dengan univariat dan bivariat dan uji statistik Chi-Square. Hasil penelitian menemukan 58,1\% penjahit mengalami keluhan berat Low Back Pain. 72,1 \% tergolong usia berisiko, 74,1 \% berjenis kelamin perempuan, 58,1\% memiliki IMT yang Berisiko, 67,4\% bekerja dengan durasi kerja berisiko, $69,8 \%$ bekerja dengan postur kerja beresiko. Ada hubungan usia $(p=0,017), I M T$ ( $p=$ $0,013)$, durasi kerja $(p=0,002)$, dan postur tubuh $(p=0,006)$ dengan keluhan Low Back Pain.Untuk mengurangi risiko Low Back Pain, penjahit agar melakukan relaksasi dan istirahat dengan peregangan otot, olahraga berdasarkan usia pekerja, mengkonsumsi makanan yang mengandung kalsium, bekerja dengan waktu kerja yang seimbang dan melakukan sistem kerja yang ergonomis.
\end{abstract}

Kata kunci : Low Back Pain (LBP); working duration;Tailors

\section{PENDAHULUAN}

Penyakit akibat kerja merupakan penyakit yang timbul karena hubungan dengan kerja (PAHK). Penyakit ini mempunyai kaitan dengan faktor pekerjaan beserta faktor lain dalam 
berkembangnya penyakit. Salah satu penyakit akibat hubungan kerja yang menjadi masalah kesehatan yang diderita pekerja adalah Nyeri Punggung Bawah/Low Back Pain (LBP). ${ }^{1}$

Low Back Pain merupakan bagian dari Penyakit Musculosceletal Dissorders (MSD). Penyakit ini ditandai dengan rasa nyeri yang dirasakan pada punggung bawah yang sumbernya yaitu tulang belakang daerah spinal, otot, saraf, atau struktur lainnya yang ada disekitar daerah tersebut. Berdasarkan ilmu medis rasa nyeri tersebut disebabkan oleh kelainan yang berasal dari luar punggung bawah misalnya penyakit pada pinggang, hernia ingunalis, dan penyakit atau kelainan pada ovarium dan testis. ${ }^{2}$

Menurut laporan Riset Kesehatan Dasar Nasional (RISKESDAS) 2018, prevalensi nyeri muskuloskeletal, termasuk Low Back Pain, oleh Badan Penelitian dan Pengembangan Kesehatan digambarkan sebagai wabah, Prevalensi penyakit Musculoskeletal Disorders di Indonesia berdasarkan pernah didiagnosis oleh tenaga kesehatan yaitu 11,9\%. Prevalensi penyakit Muculoskeletal Disorders tertinggi berdasarkan pekerjaan adalah pada petani, nelayan buruh dan jasa yaitu sebanyak $9.90 \%{ }^{3}$

Studi Kementerian Kesehatan tentang masalah kesehatan Indonesia tahun 2015 menunjukkan sekitar 40,5\% penyakit yang di derita pekerja berhubungan dengan pekerjaan. Berdasarkan penelitian terhadap 9.482 tenaga kerja di 12 wilayah / kota di Indonesia, gangguan kesehatan yang dialami oleh tenaga kerja paling banyak ditemukan pada penyakit Muskuloskeletal Dissorders (MSD) (16\%), disusul penyakit kardiovaskuler $(8 \%)$ dan penyakit saraf $(5 \%)$. Dan penyakit pernapasan. $(3 \%)$ dan penyakit THT $(1,5 \%) .{ }^{4}$

Berbagai literatur menyebutkan banyak Faktor risiko yang berkaitan dengan timbulnya Low Back Pain. Dari berbagai faktor tersebut, beberapa diantaranya yang akan diuraikan dan diteliti adalah durasi kerja dan postur kerja. Kedua faktor dipilih karena lebih memungkinkan untuk dilakukan perbaikan jika terbukti menjadi faktor yang berhubungan.

Durasi kerja adalah waktu kerja pekerja dalam melakukan pekerjaannya. Terkait dengan hal tersebut, Low Back Pain merupakan gejala yang membutuhkan waktu lama untuk berkembang dan bermanifestasi. Durasi mengacu pada jumlah waktu yang diperlukan pekerja untuk terpajan oleh faktor risiko. Pekerjaan yang membutuhkan penggunaan otot atau gerakan yang sama dalam jangka waktu yang lama meningkatkan kemungkinan kelelahan lokal dan umum. Secara umum, semakin lama periode kerja, maka semakin lama waktu pemulihan otot atau istirahat yang dibutuhkan.,

Suma'mur (2009) menjelaskan bahwa waktu kerja bagi seorang tenaga kerja dalam melakukan pekerjaan sebaiknya 6-8 jam/hari. ${ }^{2}$ Prastuti (2020) menemukan bahwa terdapat hubungan yang signifikan lama kerja dengan kejadian Low Back Pain dengan $\mathrm{P}$ value sebesar 0,0001 ( $\mathrm{P}<0,05$ ). OR (Odds Ratio) 13.929 dengan $\mathrm{Cl}$ (Confidence Interval) 95\% antara 5.167 sampai 37.548). Dimana dari hasil penelitian ini menunjukkan penjahit yang 
bekerja dengan durasi kerja > 8 jam berisiko 14 kali mengalami kejadian Low Back Pain dibandingkan penjahit dengan durasi kerja $\leq 8$ jam. ${ }^{7}$

Menurunnya efisiensi dalam bekerja menyebabkan timbulnya kelelahan, penyakit dan kecelakaan dapat terjadi akibat jam kerja pekerja yang melebihi batas. Frekuensi kerja berkaitan dengan keadaan fisik tubuh pekerja. Pekerjaan fisik yang berat akan mempengaruhi kerja otot. Jika pekerjaan berlangsung lama tanpa istirahat yang cukup, maka kemampuan tubuh akan menurun dan dapat menyebabkan kesakitan pada anggota tubuh $^{8}$

Pheasant dalam Aryanto (2008) mendefinisikan postur tubuh sebagai orientasi relatif dari bagian tubuh terhadap ruang. Untuk melakukan orientasi tubuh tersebut selama beberapa rentang waktu dibutuhkan kerja otot untuk menyangga atau menggerakkan tubuh. Postur yang diadopsi oleh manusia saat melakukan beberapa pekerjaan adalah hubungan antara dimensi tubuh sang pekerja dengan dimensi beberapa benda di dalam lingkungan kerjanya. Postur kerja yang berbahaya bagi kesehatan dan paling berisiko menimbulkan cedera adalah postur janggal. Postur janggal merupakan posisi tubuh/segmen tubuh yang menyimpang secara signifikan dari posisi yang normal. ${ }^{9,10}$

Postur tubuh menentukan sendi dan otot yang digunakan dalam suatu kegiatan. Selain itu postur tubuh juga menentukan jumlah gaya atau tegangan yang dihasilkan oleh suatu pekerjaan. Contohnya, stres pada tulang punggung belakang lebih sering terjadi pada saat mengangkat, menurunkan, atau penanganan benda dengan punggung membungkuk atau memutar, dibandingkan dengan ketika punggung lurus. Selanjutnya pekerjaan yang dilakukan dengan membungkuk atau memutar pergelangan tangan, lutut, pinggul, atau bahu juga memberikan tekanan yang berlebih terhadap otot dan sendi sehingga muncul keluhan nyeri punggung bawah ${ }^{4,11}$

Posisi dan lama duduk dalam bekerja sering diabaikan, padahal kondisi ini penting karena mengandung prinsip ergonomis. Pada lingkungan tempat kerja, duduk merupakan satu dari empat aktivitas yang umum dilakukan. Dua komponen terkait saat duduk yaitu, posisi dan lama duduk. ${ }^{12}$ Menurut Hasil penelitian Fitri Wijayanti,dkk (2019) tentang "Kejadian Low Back Pain ( LBP ) pada Penjahit Konveksi di Kelurahan Way Halim Kota Bandar Lampung" menunjukkan bahwa terdapat hubungan yang bermakna lama duduk dan posisi duduk responden terhadap kejadian Low Back Pain pada penjahit konveksi di Kelurahan Way Halim Kota Bandar Lampung. ${ }^{13}$ Ezadinita (2016) menemukan bahwa penjahit yang mengalami keluhan Low Back Pain berat sebesar 55,8\%, dan 51\% diantaranya adalah penjahit dengan posisi duduk tidak ergonomis. ${ }^{14}$

Oleh sebab itu melalui pertimbangan-pertimbangan di atas perlu dilakukan penelitian tentang durasi kerja dan postur tubuh pada penjahit karna para penjahit sektor informal perlu mendapatkan perhatihan yang cukup serius oleh pemerintah dan ahli-ahli K3. 
Mengingat bahwa banyaknya populasi penjahit dan juga melihat upah kerja yang rendah serta tidak mendapatkan kompensasi pelayanan kesehatan kerja secara gratis oleh pemerintah setempat. ${ }^{13}$

Hal ini terjadi di Nagari Simpang Kapuak di Kabupaten Lima Puluh Kota, menurut data Badan Pusat Statistik Kabupaten Lima Puluh Kota tahun 2020 Nagari Simpang Kapuak merupakan salah satu dari 5 nagari yang berada di Kecamatan Mungka Kabupaten Lima Puluh Kota. Nagari Simpang Kapuak merupakan nagari terluas di Kecamatan Mungka dengan luas wilayah seluas $36,35 \mathrm{~km}^{2}$ dan juga merupakan nagari yang memiliki jorong terbanyak yaitu sebanyak 6 jorong. Jumlah penduduk Nagari simpang kapuak adalah 4.640 jiwa dengan jumlah penduduk laki-laki 2.281 jiwa dan jumlah penduduk perempuan 2.359 jiwa. $^{15}$

Pekerjaan masyarakat di Nagari Simpang Kapuak beragam mulai di bidang pertanian, di bidang jasa dan lain lain. Salah satunya pekerjaan dibidang jasa di nagari ini adalah penjahit. Di nagari Simpang Kapuak permintaan konsumen pada penjahit setiap harinya tinggi dari berbagai kalangan seperti pekerja kantoran baik itu dari staf pemerintah ataupun swasta, anak sekolah, dan orderan menjelang lebaran membuat penjahit hanya mementingkan target dan upah saja, tanpa memperhatikan kesehatan dan kualitas pakaian yang dihasilkan. Sehingga banyaknya konsumen kecewa atas ketidakpuasan hasil kerja dari penjahit tersebut. Dari beberapa fenomena yang dipaparkan, penelitian ini bertujuan untuk mengetahui hubungan durasi kerja dan postur tubuh dengan keluhan Low Back Pain pada penjahit di nagari Simpang Kapuak Kabupaten Lima Puluh Kota Tahun 2021.

\section{METODE PENELITIAN}

Penelitian ini merupakan penelitian observasional dengan pendekatan crossectional. Variabel dependen keluhan LBP serta variabel pengaruh durasi kerja dan postur tubuh dikukur diobservasi dalam waktu yang sama. Keluhan LBP diukur dengan menggunakan kuisioner The Pain And Stress Scale yang dikategorikan menjadi keluhan berat bila score individu sama atau lebih besar dengan nilai rata-rata hasil pengukuran, dan ringan bila score individu kecil dari rata-rata. Variabel Durasi kerja diukur melalui wawancara dan observasi yang dikategorikan menjadi berisiko apabila waktu kerja lebih dari 8 jam, dan tidak berisiko bila durasi kerja 8 jam atau kurang. Variabel postur kerja diukur dengan instrumen REBA yang dikategorikan menjadi berisiko bila score individu 8 atau lebih dan tidak berisiko bila kurang dari 8.

Populasi penelitian ini adalah seluruh penjahit di Nagari Kapuak Kabupaten Lima Puluh Kota yang berjumlah 43 orang. Pengumpulan data dilakukan pada Bulan Juni 2021 selama 7 hari. Pengolahan data dilakukan dengan secara manual. Penyajian data dilakukan dengan menggunakan tabel distribusi frekuensi. Analisis data dilakukan secara univariat 
untuk mengetahui persebaran variabel yang terbagi berdasarkan titik potong (cut-up point) yang ditetapkan, serta analisis bivariat utuk melihat hubungan simultan variabel independen (durasi kerja, postur kerja) dengan variabel dependen (keluhan LBP), dengan menggunakan metode statistik non patrametrik Chi Square.

\section{HASIL PENELITIAN}

\section{Keluhan LBP}

Hasil penelitian menunjukkan jumlah dan sebaran keluhan Low Back Pain (LBP) pada penjahit di Nagari Simpang Kapuak Kabupaten Lima Puluh Kota Tahun 2021, dapat dilihat pada Tabel 1 berikut :

Tabel 1. Distribusi Penjahit Menurut Keluhan Low Back Pain (LBP)

\begin{tabular}{cccc}
\hline No & Tingkat Keluhan & $\mathbf{N}$ & $\%$ \\
\hline 1 & Berat & 25 & 58,1 \\
\hline 2 & Ringan & 18 & 41,9 \\
\hline & Total & 43 & 100,0 \\
\hline
\end{tabular}

Tabel 1 memperlihatkan bahwa Penjahit di Nagari Kapau Kabupaten Lima Puluh Kota Tahun 2021 lebih dari separuh (58,1 \%) menderita keluhan Low Back Pain (LBP) dengan kategori berat.

\section{Durasi Kerja}

Tabel 2 memperlihatkan sebaran penjahit di Nagari Kapau menurut Durasi Kerja (lamanya bekerja dalam sehari):

\begin{tabular}{cccc}
\multicolumn{4}{c}{ Tabel 2. Distribusi Penjahit Menurut Durasi Kerja } \\
\begin{tabular}{cccc} 
No & Durasi Kerja & N & $\%$ \\
\hline 1 & Berisiko & 29 & 67,4 \\
\hline 2 & Tidak Berisiko & 14 & 32,6 \\
\hline & Total & 43 & 100,0 \\
\hline
\end{tabular}
\end{tabular}

Tabel 2 memperlihatkan bahwa penjahit di Nagari Kapuak Kabuoaten Lima Puluh Kota lebih dari separoh $(67,4 \%)$ bekerja lebih dari 8 jam sehari yang termasuk dalam kategori berisiko untuk menderita keluhan LBP.

\section{Postur Tubuh}

Tabel 3 memperlihatkan sebaran penjahit yang dikelompokkan berdasarkan postur tubuh waktu bekerja. Sebaran tersebut dapat dilihat pada tebel berikut:

Tabel 3. Distribusi Penjahit Menurut Postur Tubuh Waktu Bekerja

\begin{tabular}{cccc}
\hline No & Postur Tubuh & $\mathbf{N}$ & $\%$ \\
\hline 1 & Berisiko & 30 & 69,8 \\
\hline 2 & Tidak Berisiko & 13 & 30,2 \\
\hline Total & 43 & 100,0 \\
\hline
\end{tabular}

Tabel 3 memperlihatkan bahwa penjahit di Simpang Kapuak Kabupaten Lima Puluh Kota tahun 2021 lebih dari separoh bekerja dengan postur tubuh yang berisiko untuk mengalami keluhan Low Back Pain (LBP). 


\section{Hubungan Durasi Kerja dengan Keluham Low Back Pain}

Tabel 4 menghubungan variebel durasi kerja dengan keluhan Low Back Pain pada penjahit di Nagari Simpang Kapuak Kabupaten Lima Puluh Kota Tahun 2021. Hasil dapat dilihat pada tabel dibawah ini :

Tabel 4. Hubungan Durasi Kerja Dengan Keluhan Low Back Pain

\begin{tabular}{lccccccc}
\hline \multirow{2}{*}{ Durasi kerja } & \multicolumn{3}{c}{ Keluhan Low Back Pain } & \multicolumn{2}{c}{ Jumlah } & \multirow{2}{*}{$\boldsymbol{P}$} \\
\cline { 2 - 7 } & Berat & \multicolumn{3}{c}{ Ringan } & & value \\
\cline { 2 - 7 } & $\mathbf{F}$ & $\%$ & $\mathbf{f}$ & $\%$ & $\mathbf{f}$ & $\%$ & \\
\hline Berisiko & 22 & 75,9 & 7 & 24,2 & 29 & 100 & $\mathbf{0 , 0 0 2}$ \\
\hline Tidak Berisiko & 3 & 21,4 & 11 & 78,6 & 9 & 100 & \\
\hline Jumlah & 25 & 58,1 & 18 & 41,9 & 43 & 100 & \\
\hline Berisiko & 22 & 75,9 & 7 & 24,2 & 29 & 100 & \\
\hline
\end{tabular}

Tabel 4 memperlihatkan bahwa proporsi penjahit yang mengalami LBP lebih tinggi pada yang bekerja lebih dari 8 jam sehari (berisiko) jika dibandingkan dengan pada kelompok yang bekerja 8 jam atau kurang. Uji yang dilakukan dengan metode Chi square menunjukkan bahwa nilai $p$-value $<0.05(p=0,002)$. Hal ini menunjukkan terdapat perbedaan proporsi bermakna kedua kelompok, yang dapat diartikan bahwa terdapat hubungan durasi kerja dengan keluhan Low Back Pain.

\section{Hubungan Postur Tubuh dengan Keluhan Low Back Pain}

Hasil analisis hubungan postur tubuh dengan keluhan Low Back Pain pada penjahit di Nagari Simpang Kapuak Kabupaten Lima Puluh Kota Tahun 2021 dapat dilihat pada tabel dibawah ini :

Tabel 5. Hubungan Postur Tubuh Dengan Keluhan Low Back Pain Pada Penjahit

\begin{tabular}{|c|c|c|c|c|c|c|c|}
\hline \multirow{3}{*}{ Postur tubuh } & \multicolumn{4}{|c|}{ Keluhan Low Back Pain } & \multirow{2}{*}{\multicolumn{2}{|c|}{ Jumlah }} & \multirow{3}{*}{$\begin{array}{c}P \\
\text { value }\end{array}$} \\
\hline & \multirow{2}{*}{$\begin{array}{c}\text { Berat } \\
\text { F }\end{array}$} & \multicolumn{3}{|c|}{ Ringan } & & & \\
\hline & & $\%$ & f & $\%$ & $f$ & $\%$ & \\
\hline Berisiko & 22 & 73,3 & 8 & 26,7 & 30 & 100 & 0,006 \\
\hline Tidak Berisiko & 3 & 23,1 & 10 & 76,9 & 13 & 100 & \\
\hline Jumlah & 25 & 58,1 & 18 & 41,9 & 43 & 100 & \\
\hline
\end{tabular}

Tabel 5 memperlihatkan bahwa proporsi penjahit yang mengalami LBP lebih tinggi pada yang bekerja dengan postur tubuh yang berisiko jika dibandingkan dengan pada kelompok yang bekerja dengan postur tubuh yang tidak berisiko. Uji yang dilakukan dengan metode Chi square menunjukkan bahwa nilai $p$-value $<0.05$ ( $p=0,006)$. Hal ini menunjukkan terdapat perbedaan proporsi bermakna antara kedua kelompok, yang dapat diartikan bahwa terdapat hubungan postur kerja dengan keluhan Low Back Pain.

\section{PEMBAHASAN}

Pekerjaan menjahit di Nagari Kapuak merupakan kegiatan industri rumah tangga yang dilakukan dengan peralatan manual. Pekerjaan tersebut merupakan usaha keluarga yang 
kurang terikat dengan peraturan ketenagakerjaan dan kesehatan dan keselamatan kerja. Kondisi demikian menyebabkan aturan-aturan tentang kesehatan dan keselamatan kerja kurang mendapat perhatian dari pekerja.Proporsi yang mengalami keluhan LBP masih tinggi di kalangan penjahit. Fenomena ini sejalan dengan penelitian-penelitian sejenis di tempat lain. Hal ini menunjukkan bahwa pekerjaan menjahit memang merupakan pekerjaan yang berisiko untuk mengalami keluhan LBP. Hal ini tidak terlepas dari sifat pekerjaan yang dilaksanakan dalam posisi duduk dalam jangka waktu lama dengan gerakan otot yang cenderung monoton.

Keluhan LBP yang tinggi di kalangan penjahit perlu diberikan solusi oleh pihak terkait, seperti Dinas Kesehatan atau Dinas Ketenagakerjaan, serta upaya-upaya pencegahan oleh penjahit itu sendiri. Pembinaan tersebut mengangkut upaya pencegahan, serta memperkecil gejala bagi yang sudah terlanjut mengalami. Dengan demikian LBP yang dialami dapat sembuh, atau tidak semakin parah yang dapat mengganggu pekerjaan. Bagi yang belum mengalami, dapat melakukan upaya-upaya pencegahan dengan tepat yang didasarkan pada ilmu pengetahuan.

Proporsi penjahit yang bekerja lebih dari ketentuan jam kerja juga masih terjadi pada Penjahit di Nagari Kapuak. Usaha yang bersifat usaha keluarga memang tidak terikat dengan jam kerja, akan tetapi sangat ditentukan oleh target produksi yang harus diselesaikan dan rasa lelah yang yang dirasakan oleh pekerja. Banyaknya pekerja yang bekerja melebihi jam kerja juga perlu materi pembinaan oleh dinas terkait. Hal ini penting karena jam kerja 8 jam perhari ditetapkan sesuai dengan kondisi fisiologis dan psikologis manusia yang memerlukan istirahat. Postur tubuh penjahit dalam bekerja juga masih banyak yang mengundang risiko LBP. Kondisi juga sejalan dengan yang ditemukan oleh peneliti lain di tempat yang berbeda. Postur tubuh yang janggal pada pekerjaan menjahit yang dikelola oleh usaha keluarga memang sering ditemukan. Hal ini terjadi antara lain karena peralatan yang digunakan dirancang sendiri atau dirancang bukan untuk jenis pekerjaan tersebut, sehingga tubuh pekerja harus melakukan penyesuaian dengan peralatan kerja yang digunakan.

Hubungan bermakna variabel independen dengan variabel dependen menunjukkan bahwa kedua variabel independen perlu dimanipulasi untuk mencegah antau menurunkan keluhan LBP pada penjahit.Durasi kerja sebagai salah satu faktor risiko dalam penelitian ini berhubungi secara bermakna dengan keluhan LBP. Fenomena ini juga ditemukan pada penelitian-penelitian lain dengan pekerjaan sejenis di tempat lain. Hal ini membuktikan bahwa durasi kerja secara konsisten menjadi faktor risiko bagi keluhan LBP. 


\section{SIMPULAN DAN SARAN}

Penjahit di Nagari Kapuak Kabupaten Lima Puluh Kota yang mmengalami keluhan LBP lebih dari separoh. Penjahit yang mengalami keluhan LBP proporsinya lebih tinggi pada pekerja yang bekerja lebih dari 8 jam sehari. Hal serupa juga terjadi pada pekerja yang bekerja dengan postur tubuh yang salah saat bekerja. Ditemukan adanya hubungan bermakna durasi kerja dan postur tubuh dengan keluhan LBP pada penjahit. Hal yang direkomendasikan kepada penjahit yaitu melakukan relaksasi dan aktifitas fisik, bekerja dengan jam kerja yang sesuai dengan jam kerja normal 8 jam sehari serta menggunakan peralatan kerja yang ergonomis.

\section{DAFTAR PUSTAKA}

1. Kementerian Tenaga Kerja dan Transmigrasi Republik Indonesia. Undang-Undang RI Nomor 13 Tahun 2003 Tentang Ketenagakerjaan. 2003;1-84.

2. Suma'mur. Higiene Perusahaan Dan Kesehatan Kerja (Hiperkes). Jakarta: CV Sagung Seto; 2009.

3. Riset Kesehatan Dasar 2018. 2018;

4. Sekaaram, Dkk. Prevalensi Musculoskeletal Disorders (MSDs) pada Pengemudi Angkutan Umum di Terminal Mengwi, Kabupaten Badung-Bali. Jurnal Kesehatan. 2017;8(2):118-24.

5. Lawrence, Fine J, Dkk. Element Of Ergonomic Programs "A Primer Based On Workplace Evalutions Of Musculosketal Disorder." Columbia: NIOSH; 1997.

6. Levy J. Ergonomics. Bandung: PT Remaja Rosdakarya; 2006.

7. Prastuti, Betty., Sintia, Ine., \& Ningsih, Kursiah Warti. 2020. Hubungan Lama Kerja dan Posisi Duduk Terhadap Kejadian Low Back Pain Pada Penjahit di Kota Pekanbaru. Jurnal Endurance: Kajian Ilmiah Problema Kesehatan, Volume 5, No. 2.

8. C T, ME. P. Kesehatan Lingkungan dan K3. Yogyakarta: Nuha Medika; 2013.

9. Pheasant,stephent 2003. Bodyspace: Antropometry, Ergonomic and the Designof Work $2^{\text {nd }}$ Edition. USA : Taylor \& Francis

10. Aryanto D. Gambaran Risiko Ergonomi dan Keluhan Musculoskeletal Pada . Jurnal Kesehatan. 2018

11. Humantech. Apllied Ergonomics Training Manual Second Edition Berkeley Vale. Australia: Proeter and Gamble Ine; 1995.

12. Osni M. Gambaran Faktor Risiko Ergonomi dan Keluhan Subjektif Musculosketal Disorder Pada Pejahit Sektor Informal di Kawasan Home Industri RW 6 Kelurahan Cipadu Kec. Larangan Kota Tanggerang Tahun 2012. skripsi. 2012; 
13. Wijayanti, Fitri Oktafany Ramadhian, M R. Kejadian Low Back Pain ( LBP ) pada Penjahit Konveksi di Kelurahan Way Halim Kota Bandar Lampung. Jurnal Kedokteran. 2019;8:82-8.

14. Silvi Ezadinita. Faktor-faktor yang berhubungan dengan keluhan low back pain pda pekerja cetak batu bata di nagari padang sibusuk kabupaten sijunjung Tahun 2016. Univ Andalas. 2016;

15. Badan Pusat Statistik Kabupaten Lima Puluh Kota. 2019; 